\title{
Kedudukan Peraturan Daerah Dalam Hierarki Peraturan Perundang-undangan
}

\section{Ni'matul Huda}

\begin{abstract}
The mechanism procedure of establishing bylaws is the same with Act and the posisition of bylaw is equal with the Act, in the sense, that bylaws and Act are legislative products. However, the contain of bylaws is different with the Act. The implementation of bylaws is limited to a certain region, othenwise the Act is implemented in the national level. Thus, the hierarchy of bylaw is lower than the Act.
\end{abstract}

Abstrak

\section{Pendahuluan}

Beberapa saat yang lalu berbagai media cetak memberitakan adanya sejumlah Peraturan Daerah dan beberapa peraturan perundang-undangan di daerah dari berbagai pelosok tanah air yang akan dibatalkan oleh Pemerintah karena bertentangan dengan peraturan perundang-undangan yang lebih tinggi. Dan tidak sedikit produk Perda yang ditolak oleh masyarakat karena Perda tersebut justru memberatkan masyarakat di daerah yang bersangkutan, entah karena alasan memberatkan usaha petani dan pengusaha di daerah atau karena dipandang membatasi ruang gerak masyarakat untuk beraktifitas.

Sejak tahun 2000, melalui Ketetapan MPR No. III/MPR/2000 tentang Sumber Hukum dan Tata Urutan Peraturan Perundang-undangan, jenis peraturan daerah (perda) sudah secara resmi menjadi sumber hukum dan masuk dalam tata urutan peraturan perundangundangan. Di dalam Pasal 3 ayat (7) Tap tersebut ditegaskan bahwa peraturan daerah ${ }^{\text {i }}$ merupakan peraturan untuk melaksanakan aturan hukum di atasnya dan menampung kondisi khusus dari daerah yang bersangkutan. Kemudian dalam Pasal 4 ayat (1) dinyatakan, sesuai dengan tata urutan peraturan perundang-undangan ini, maka setiap aturan hukum yang lebih rendah tidak boleh bertentangan dengan aturan hukum yang lebih tinggi.

Sejak otonomi daerah digulirkan tahun 1999, sudah ribuan Perda diproduksi oleh sejumlah daerah di Indonesia tetapi kesadaran pemerintah daerah untuk melaporkan peraturan-peraturan daerah yang sudah dikeluarkan kepada pemerintah pusat masih rendah. Dari total peraturan daerah yang diterbitkan sekitar 13.520 peraturan, hanya 5.054 peraturan yang telah dilaporkan kepada Departemen Dalam Negeri, sehingga Pemerintah sulit untuk bisa memantau secara langsung Perda-perda yang ada di seluruh Indonesia. Menurut Sekretaris Jenderal Departemen 
Dalam Negeri Progo Nurdjaman, dari 5.054 perda yàng mengatur pajak dan retribusi yang. diterima oleh Departemen Dalam Negeri sejak tahun 2000, diantaranya sebanyak 930 Perda layak dibatalkan dan 3.966 lainnya layak dilaksanakan. ${ }^{1}$

Penyusunan perda sebenarnya harus memenuhi tiga aspek, yakni yuridis, filosofis, dan sosiologis. Seringkali penyusunan perda mengabaikan aspek sosiologis, yakni hukum yang berlaku di masyarakat, dan karena tidak melihat potensi dan karakteristik masyarakat, implementasi perda banyak terganggu. Di samping itu, sebagian besar perda yang bermasalah umumnya bertentangan dengan aturan yang lebih tinggi, juga terjadi tumpang tindih antara kebijakan pusat dan daerah serta tumpang tindih antara pajak dan retribusi. Sebagian besar pejabat di daerah yang tidak memahami undang-undang memaksakan perda yang berorientasi kepada keuntungan jangka pendek tanpa memikirkan akibat jangka panjangnya.

Ada sejumlah kalangan masyarăkat yang mempertanyakan apa maksud dari ketentuan yang menyatakan "setiap aturan hukum yang lebih rendah tidak boleh bertentangan dengan aturan hukum yang lebih tinggi." Dalam praktek di lapangan seringkali dijumpai berbagai jenis peraturan perundang-undangan yang dulu dikenal dengan nama keputusan menteri, peraturan atau keputusan MA, BPK, BI dan seterusnya. $^{2}$ Beragamnya peraturan peründang-undangan tersebut juga cukup menyulitkan pejabat daerah untuk memahaminya. Apakah peraturan-peraturan tersebut kedudukannya lebih tinggi dari peraturan daerah? Bagaimana kedudukan. perda dalam hierarki peraturan perundangundangan? Apa yang harus dilakukan pemerintah agar pejabat daerah tidak terus menerus melakukan kesalahan dalam memahami hierarki peraturan perundangundangan dan membuat peraturan daerah. Sejumlah permasalahan ini layak untuk dikemukakan karena pemahaman masyarakat terhadap otonomi daerah sangat beragam, sehingga perlu ditegaskan koridor otonomi' daerah dalam bingkai yang jelas agar tidak keluar jauh dari rel yang sudah disepakati bersama dan membahayakan eksistensi Negara Kesatuan Republik Indonesia.

\section{Hierarki Norma Hukum}

Tidak ada suatu sistem hukum positif di dunia ini yang secara khusus mengatur tata urutan peraturan perundang-undangan. Kalaupun ada pengaturan hanya terbatas pada asas yang menyebutkan misalnya: "Peraturan Daerah tidak boleh bertentangan dengan peraturan perundang-undangan yang lebih tinggi tingkatannya" atau dalam hal UUD ada ungkapan "the supreme law of the land." Mengapa tidak diatur? Antara lain karena tata urutan itu mempunyai konsekuensi, bahkan setiap

${ }^{1}$ Kompas, Sabtu, 1 April 2006, him. 34.

2 Lihat Penjelasan Pasal 7 ayat:(4) UU No. 10 Tahun 2004 tentang Pembentukan Peraturan Perundangundangan. Jenis peraturan perundang-undangan selain yang telah diatur dalam hierarki Pasal 7 ayat (1), antara lain, peraturan yāng dikeluarkan oleh MPR dan DPR, DPD, MA, MK, BPK, BI, Menteri, kepala badan, lembaga, atau komisi, DPRD Provinsi, Gubemur, DPRD Kabupaten/Kota, BupatiWalikota, Kepala Desa atau yang setingkat. 
peraturan perundang-undangan harus memiliki dasar hukum pada peraturan perundangundangan yang lebih tinggi tingkatannya. Peraturan perundang-undangan tingkatan lebih rendah tidak boleh bertentangan dengan peraturan perundang-undangan yang lebih tinggi. Apabila ternyata peraturan perundangundangan yang lebih rendah tingkatannya bertentangan dengan peraturan perundangundangan yang lebih tinggi, peraturan perundang-undangan tingkatan lebih rendah dapat dituntut untuk dibatalkan bahkan batal demi hukum (van rechtswege nietig). Konsekuensi ini. telah dianggap ada walaupun tidak diatur, kecuali ada ketentuan yang sebaliknya, misalnya dalam UUD (seperti UUDS 1950 dan KRIS) disebutkan "undang-undang tidak dapat diganggu gugat". Di sini prinsip tata unutan tidak berlaku. Undangundang (formal) akan tetap berlaku dan harus diterapkan walaupun bertentangan dengan UUD sebagai peraturan perundang-undangan yang lebih tinggi tingkatannya. Prinsip atau ketentuan yang menyebutkan: "undangundang tidak dapat diganggu gugat" bertalian dengan ajaran "supremasi parlemen". Di sini, UUD lebih dipandang sebagai "asas-asas umum" daripada sebagai kaidah hukum. ${ }^{3}$

Faktor lain yang menyebabkan tidak ada kelaziman mengatur tata urutan peraturan perundang-undangan, karena sistem hukum positif tidak hanya berupa peraturan perundangundangan, melainkan meliputi juga hukumhukum tidak tertulis (yurisprudensi, hukum adat, atau hukum kebiasaan). Kaidah-kaidah hukum tidak tertulis ini dapat juga dipergunakan untuk menguji peraturan perundang-undangan atau sebaliknya, walaupun tidak bertalian dengan tata urutan peraturan perundang-undangan. $\mathrm{Di}$ Inggris, peraturan perundang-undangan di bawah undang-undang (delegated legislation) dapat diuji terhadap common law dan prinsipprinsip umum seperti prinsip "bias, ultra vires" dan lain-lain. Di Belanda, peraturan atau keputusan administrasi negara dapat diuji terhadap asas-asas umum penyelenggaraan administrasi negara yang baik (beginselen van behoorlijk bestuur).

Secara teoritik, tata urutan peraturan perundang-undangan dapat dikaitkan dengan ajaran Hans Kelsen mengenai Stufenbau des Recht atau The hierarchy of lawyang berintikan bahwwa kaidah hukum merupakan suatu susunan berjenjang dan setiap kaidah hukum yang lebih rendah bersumber dari kaidah yang lebih tinggi. Untuk lebih memahami teori Stufenbau des Recht, harus dihubungkan dengan ajaran Kelsen yang lain yaitu Reine Rechtslehre atau The pure theory of law (teori murni tentang hukum) dan bahwa hukum itu tidak lain "command of the sovereign" kehendak yang berkuasa. ${ }^{4}$

Hans Kelsen mengatakan bahwa hukum termasuk dalam sistem norma yang dinamik (nomodynamics) karena hukum itu selalu dibentuk dan dihapus oleh lembaga-lembaga atau otoritas-otoritas yang berwenang membentuknya, sehingga dalam hal ini tidak kita lihat dari segi isi norma tersebut, tetapi dari segi berlakunya atau pembentukannya. ${ }^{5}$

Hukum itu adalah sah (valid) apabila

${ }^{3}$ Bagir Manan, Teoridan Politik Konstitusi, Cetakan Kedua, (FH Ull Press, Yogyakarta, 2004), hlm. 201-202.

${ }^{4}$ Ibid., hlm. 203.

${ }^{5}$ Hans Kelsen, General Theory of Law and State, (Translate by Anders Wedberg, Russell \& Russell, New York, 1973), hlm. 112-113. 
dibuat oleh lembaga atau otoritas yang berwenang membentuknya dan berdasarkan noma yang lebih tinggi sehingga dalam hal ini norma yang lebih rendah (inferior) dapat dibentuk oleh norma yang lebih tinggi (superior), dan hukum itu berjenjang-jenjang dan berlapislapis membentuk hierarki, di mana suatu norma yang lebih rendah berlaku, bersumber, dan berdasar pada norma yang lebih tinggi, norma yang lebih tinggi berlaku, bersumber dan berdasar pada norma yang lebih tinggi lagi, demikian seterusnya sampai pada suatu norma yang tidak dapat ditelusuri lebih lanjut dan bersifat hipotetis dan fiktif, yaitu norma dasar (grundnorm).

Tata urutan atau hierarki peraturan perundang-undangan dalam suatu tata hukum itu oleh Hans Kelsen disebut hierarchi of norm (strufenbau des recht). ${ }^{6}$ Setiap tata kaidah hukum merupakan suatu susunan daripada kaidah-kaidah. Dalam stufentheorie-nya Hans Kelsen mengemukakan bahwa dipuncak "stufenbau" terdapat kaidah dasar dari suatu tata hukum nasional yang merupakan suatu kaidah fundamental. Kaidah dasar tersebut disebut. "grundnorm" atau "ursprungnorm". Grundnorm merupakan asas-asas hukum yang bersifat abstrak, bersifat umum, atau hipotetis.

Sistem hukum suatu negara merupakan suatu proses yang terus menerus, dimulai dari yang abstrak, menuju ke hukum yang positif, dan seterusnya sampai menjadi nyata. Semua norma merupakan satu kesatuan dengan struktur piramida. Dasar keabsahan suatu norma ditentukan oleh norma yang paling tinggi tingkatannya. Jadi menurut Hans Kelsen urutan norma itu dimulai dari Grundnorm atau Ursprungsnorm ke Generallenorm, kemudian dipositifkan. Sesudah itu akan menjadi norma nyata (Concretenorm). Norma nyata lebih bersifat individual. Oleh karena norma positif merupakan "perantara" dari norma dasar dengan norma individual, maka disebut juga norma antara (Tussennorm).

Lebih lanjut Kelsen mengatakan, norma hukum (legal norm) dapat dibedakan antara general norm dan individual norm. Termasuk dalam general norm adalah custom dan legislation. Hukum yang diciptakan oleh custom disebut customary law, sedangkan hukum yang diciptakan oleh badan legislatif (law created by legislative) disebut statute. Kemudian, norma-norma individual meliputi "putusan badan administrasi" disebut "administrative acts", dan "transaksi hukum" atau "legal transaction" yaitu berupa contract dan treaty.

Dalam hubungannya dengan UndangUndang Dasar (UUD) atau konstitusi, Kelsen menyatakan bahwa UUD menduduki tempat tertinggi dalam hukum nasional, sebab itu merupakan landasan bagi sistem hukum nasional. Undang-Undang Dasar merupakan fundamental law. Untuk itu Hans Kelsen menunjuk hak menguji sebagai mekanisme "guarantees of the constitution." Jadi dapat dikatakan bahwa hak menguji merupakan konsekuensi dari konstitusi tertulis, atau yang oleh Kelsen disebut konstitusi dalam arti formal, atau konstitusi dalam arti sempit. ${ }^{9}$

Teori Hans Kelsen tersebut-kemudian

\footnotetext{
${ }^{6} /$ bid., hlm. 114-115.

${ }^{7} \mathrm{bid}$.

${ }^{8}$ Ibid., hlm. 124.

${ }^{9}$ K.C. Wheare, Modem Constitution, (Oxford University Press, London, 1971), hlm. 2.
} 
dikembangkan oleh Hans Nawiasky. Nawiasky dalam teorinya mengenai Die Stufenaufbau der Rechtsordnung atau Die Stufenordnung der Rechtsnormen, mengemukakan tiga lapis norma-norma hukum, yakni Grundnorm (Norma dasar), Grundgesetze (Aturan-aturan Dasar), dan formelle Gesetze (Peraturan Perundang-undangan) berikut Verordnungen serta autonome Satzungen yang dapat digolongkan ke dalam peraturan-peraturan pelaksanaan.

Menurut Nawiasky, norma-norma hukum tersebut selain berlapis-lapis juga Stufenformig (berbentuk kerucut atau seperti stupa). Diantara lapis-lapis tersebut dapat saja ada lapis-lapis lain yang merupakan bagian-bagiannya, yang disebutnya Zwischenstufe (stupa antara). Sudah tentu tiap lapisan stupa tersebut berisi normanorma hukum yang bersifat umum (generelle Normen), mengingat suatu norma hukum pada dasarnya berlaku umum, elgemeen. Norma fundamental negara yang merupakan norma tertinggi dalam suatu negara ini adalah norma yang tidak dibentuk oleh suatu norma yang lebih tinggi tetapi pre-supposed atau ditetapkan terlebih dahulu oleh masyarakat dalam suatu negara dan merupakan suatu norma yang menjadi tempat bergantungnya norma-norma hukum di bawahnya. Dikatakan bahwa norma yang tertinggi ini tidak dibentuk oleh norma yang lebih tinggi lagi karena kalau norma yang tertinggi itu dibentuk oleh norma yang lebih tinggi lagi, ia bukan merupakan norma yang tertinggi. ${ }^{10}$
Lebih lanjut Nawiasky mengatakan, isi staatsfundamentalnorm ialah norma yang merupakan dasar bagi pembentukan konstitusi atau undang-undang dasar suatu negara (staatsverfassung), termasuk norma pengubahannya. Hakikat hukum suatu staatsfundamentalnorm ialah syarat bagi berlakunya suatu konstitusi atau undangundang dasar. la ada terlebih dahulu sebelum adanya konstitusi atau undang-undang dasar.

Selain itu "Norma Dasar" (grundnorm atau disebut juga ursprungsnorm atau urnorm) sebagaimana yang disebutkan bersifat pre supposed dan tidak dapat ditelusuri lebih lanjut dasar berlakunya, sehingga tidak perlu menerimanya sebagai sesuatu yang tidak dā̄a diperdebatkan lagi, sebagai suatu hipotesis, sesuatu yang fiktif, suatu aksioma. Ini diperlukan untuk tidak menggoyahkan lapis-lapis bangunan tata hukum yang pada akhimya menggantungkan atau mendasarkan diri kepadanya. Di dalam suatu negara norma dasar ini disebut juga staatsfundamentalnorm. Staatsfundamentalnorm suatu negara merupakan landasan dasar filosofisnya yang mengandung kaidah-kaidah dasar bagi pengaturan negara lebih lanjut."

Aturan dasar (Grundgesetze) merupakan aturan-aturan yang masih bersifat pokok, bersifat dasar, dan biasanya merupakan landasan luas bagi tata hukum yang lebih terperinci lagi.

Sebagai norma dasar suatu negara (Staatsfundamentalnorm) memberikan

${ }^{10}$ A. Hamid S.Attamimi, Peranan Keputusan Presiden RI dalam Penyelenggaraan Pemerintahan Negara (Suatu StudiAnalisis Mengenai Keputusan Presiden yang Berfungsi Pengaturan dalam Kurun Waktu PelitaI - Pelita VI), Disertasi Doktor, (Pascasarjana Universitas Indonesia, Jakarta, 1990), hlm. 359 dst.

"A. Hamid S. Attamimi, "UUD 1945-TAP MPR-UNDANG-UNDANG", dalam Padmo Wahjono (Penghimpun), Masalah Kefatanegaraan Dewasa Ini, (Ghalia Indonesia, 1984), him. 125-126. 
landasan bagi aturan dasar yang merupakan tatanan suatu negara dalam bentuk UndangUndang Dasar atau konstitusi (tertulis) maka aturan dasar tersebut pada gilirannya merupakan landasan bagi hukum perundangundangan (Gesetzesrecht) yang berlaku dalam negara. Biasanya aturan-aturan dasar tersebut apabila dituangkan dalam suatu dokumen negara disebut Vervassung, dan apabila dalam beberapa dokumen atau tersebar-sebar disebut Grundgessetze. Isi penting bagi aturan dasar selain garis-garis besar atau pokokpokok kebijaksanaan negara juga terutama aturan-aturan untuk memperlakukan dan memberikan kekuatan mengikat kepada norma-norma hukum peraturan perundangundangan, atau dengan perkataan lain menggariskan tata cara membentuk peraturan perundang-undangan yang mengikat umum.

\section{Hierarki Peraturan Perundang-undangan RI}

Menurut sistem hukum Indonesia, peraturan perundang-undangan (hukum tertulis) disusun dalam suatu tingkatan yang disebut hierarki peraturan perundangundangan. Di dalam Memorandum DPR-GR tertanggal 9 Juni 1996 yang telah dikukuhkan oleh MPRS dengan Ketetapan MPRS No. XXI MPRS/1966 dan juga oleh MPR dengan Ketetapan MPR No. V/MPR/1973, Lampiran II tentang "Tata Urutan Peraturan Perundangundangan Republik indonesia Menurut UUD $1945^{\prime \prime}$ dalam huruf $A$, disebutkan tata urutan bentuk-bentuk peraturan perundangundangan Republik Indonesia ialah sebagai berikut:
Tabel 1

\section{Hierarki Peraturan Perundang- undangan}

Menurut TAP MPRS No. XX/MPRS/1966

UUD 1945,

Ketetapan MPRS/MPR,

UU/Perppu,

Peraturan Pemerintah,

Keputusan Presiden,

Peraturan-peraturan pelaksanaan lainnya seperti:

1. Peraturan Menteri,

2. Instruksi Menteri, dan lain-lainnya.

Tata urutan di atas menunjukkan tingkattingkat daripada masing-masing bentuk yang bersangkutan di mana yang disebut lebih dahulu mempunyai kedudukan lebih tinggi daripada bentuk-bentuk yang tersebut belakangnya (di bawahnya). Di samping itu, tata urutan di atas mengandung konsekuensi hukum bentuk peraturan atau ketetapan yang tingkatannya lebih rendah tidak boleh mengandung materi yang bertentangan dengan materi yang dimuat di dalam suatu peraturan yang bentuknya lebih tinggi, terlepas dari soal siapakah yang berwenang memberikan penilaian terhadap materi peraturan serta bagaimana nanti konsekuensi apabila suatu peraturan itu materinya dinilai bertentangan dengan materi peraturan yang lebih tinggi. ${ }^{12}$

Melalui Sidang Tahunan MPR Rl tanggal 7-18 Agustus 2000, MPR telah mengeluarkan Ketetapan MPR No. III/MPR/2000 tentang Sumber Hukum dan Tata Urutan Peraturan Perundang-undangan. Menurut Ketetapan

${ }^{12}$ Ni'matul Huda, Negara Hukum, Demokrasi dan Judicial Review, (Ull Press, Yogyakarta, 2005). 
MPR No. Ill/MPR/2000, peraturan perundang: undangan yang tersusun secara hierarkis tersebut mengandung konsekuensi bahwa suatu peraturan perundang-undangan yang lebih rendah tingkatannya tidak boleh bertentangan dengan peraturan perundangundangan yang lebih tinggi tingkatannya. Hal ini selaras dengan asas hukum lex superior derogat inferiori (hukum yang lebih tinggi mengalahkan hukum yang tingkatannya di bawahnya). Hal ini dimaksudkan agar tercipta kepastian hukum dalam sistem peraturan perundang-undangan:

Ajaran tentang tata urutan peraturan perundang-undangan demikian mengandung beberapa prinsip: ${ }^{13}$

1. Peraturan perundang-undangan yang lebih tinggi kedudukannya dapat dijadikan landasan atau dasar hukum bagi peraturan perundang-undangan yang lebih rendah atau berada di bawahnya.

2. Peraturan perundang-undangan tingkat lebih rendah hanus bersumber atau memiliki dasar hukum dari suatu peraturan perundang-undangan tingkat lebih tinggi.

3. Isi atau muatan peraturan perundangundangan yang lebih rendah tidak boleh menyimpangi atau bertentangan dengan peraturan perundang-undangan yang lebih tinggi tingkatannya.

4. Suatu peraturan perundang-undangan hanya dapat dicabut atau diganti atau diubah dengan peraturan perundangundangan yang lebih tinggi atau paling tidak dengan yang sederajat.

5. Peraturan-peraturan perundangundangan yang sejenis apabila mengatur materi yang sama, maka peraturan yang terbaru harus diberlakukan, walaupun tidak dengan secara tegas dinyatakan bahwa peraturan yang lama itu dicabut. Selain itu, peraturan yang mengatur materi yang lebih khusus harus diutamakan dari peraturan perundang-undangan yang lebih umum.

Konsekuensi penting dari prinsip-prinsip di atas, harus diadakan mekanisme yang menjaga dan menjamin agar prinsip tersebut tidak disimpangi atau dilanggar. Mekanismenya yaitu ada sistem pengujian secara yudisial atas setiap peraturan perundang-undangan, atau kebijakan maupun tindakan pemerintahan lainnya, terhadap peraturan perundang-undangan yang lebih tinggi tingkatannya atau tingkat tertinggi yaitu UUD. Tanpa konsekuensi tersebut, tata urutan tidak akan berarti. Suatu peraturan perundangundangan tingkat lebih rendah dapat tetap berlaku walaupun bertentangan dengan peraturan perundang-undangan tingkat lebih tinggi.

Pada tanggal 24 Mei 2004 DPR dan Pemerintah telah menyetujui Rancangan Undang-undang tentang Pembentukan Peraturan Perundang-undangan menjadi Undang (UU No. 10 Tahun 2004). Undangundang ini menegaskan bahwa Pancasila merupakan sumber dari segala sumber hukum negara. UUD Negara Republik Indonesia Tahun 1945 merupakan hukum dasar dalam peraturan perundang-undangan. Mengenai jenis dan hierarki peraturan perundang-undangan diatur dalam Pasal 7 UU tersebut adalah sebagai berikut:

${ }^{13}$ Bagir Manan, Teoridan..., Op.Cit., him. 133. Lihatjuga dalam Rosjidi Ranggawidjaja, Pedoman Teknik Perancangan Peraturan Perundang-undangan, (Cita BhaktiAkademika, Bandung, 1996), hlm. 19. 
Tabel 2

\begin{tabular}{|l|}
\hline HIERARKI MENURUT UUNO. 10TH 2004 \\
\hline a. UUD Negara RI Tahun 1945 \\
b. Undang-Undang/Perpu \\
c. Peraturan Pemerintah \\
d. Peraturan Presiden \\
e. Peraturan Daerah: \\
1. Perda Provinsi \\
2. Perda Kabupaten/Kota \\
3. Perdes/Peraturan yang Setingkat \\
\hline
\end{tabular}

Jenis peraturan perundang-undangan selain yang telah disebutkan di atas (lihat tabel 2), diakui keberadaannya dan mempunyai kekuatan hukum mengikat sepanjang diperintahkan oleh peraturan perundangundangan yang lebih tinggi, antara lain: peraturan yang dikeluarkan oleh MPR dan DPR, DPD, MA, MK, BPK, Bank Indonesia, Menteri, Kepala Badan, Lembaga atau Komisi yang setingkat yang dibentuk oleh undangundang atau pemerintah atas perintah undang-undang, DPRD Provinsi, Gubernur, DPRD Kabupaten/Kota, Bupati/Walikota, Kepala Desa atau yang setingkat.

\section{Peraturan Daerah}

Berkaitan dengan Peraturan Daerah, Pasal 7 ayat (2) UU No. 10 Tahun 2004 menegaskan sebagai berikut:

a. Perda provinsi dibuat oleh Dewan Perwakilan Rakyat Daerah provinsi bersama dengan gubernur.

b. Perda kabupaten/kota dibuat oleh Dewan Perwakilan Rakyat Daerah Kabupaten/kota bersama dengan bupati/walikota.

c. Peraturan Desa/peraturan yang setingkat, dibuat oleh Badan Perwakilan Desa atau nama lainnya bersama dengan kepala desa atau nama lainnya.

Ketentuan lebih lanjut mengenai tata cara pembuatan Peraturan Desa/peraturan yang setingkat diatur dengan peraturan daerah kabupaten/kota yang bersangkutan.

Kemudian dalam Pasal 12 ditegaskan, bahwa materi muatan Peraturan Daerah adalah seluruh materi muatan dalam rangka penyelenggaraan otonomi daerah dan tugas pembantuan, dan menampung kondisi khusus daerah serta penjabaran lebih lanjut peraturan perundang-undangan yang lebih tinggi.

Di dalam UU No. 32 Tahun 2004 tentang Pemerintahan Daerah Pasal 136 ditegaskan Perda ditetapkan oleh kepala daerah setelah mendapat persetujuan bersama DPRD. Perda dibentuk dalam rangka penyelenggaraan otonomi daerah provinsi/kabupaten/kota dan tugas pembantuan. Perda merupakan penjabaran lebih lanjut dari peraturan perundang-undangan yang lebih tinggi dengan memperhatikan ciri khas masing-masing daerah. Perda dilarang bertentangan dengan kepentingan umum dan/atau peraturan perundang-undangan yang lebih tinggi. Materi muatan Peraturan Desalyang setingkat adalah seluruh materi dalam rangka penyelenggaraan urusan desa atau yang setingkat serta penjabaran lebih lanjut peraturan perundangundangan yang lebih tinggi. Materi muatan mengenai ketentuan pidana hanya dapat dimuat dalam Undang-Undang dan Peraturan Daerah.

UU No. 32 Tahun 2004 ternyata memberikan ruang lingkup urusan pemerintahan yang sangat luas (kewenangan) kepada daerah untuk diatur dalam peraturan daerah. Ketentuan tersebut mengharuskan para pejabat di lingkungan pemerintah daerah yang ditugaskan 
untuk merancang sebuah peraturan daerah untuk mengetahui dan mempelajari berbagai peraturan perundang-undangan yang lebih tinggi yang terkait dengan substansi rancangan peraturan daerah. Penelitian dan kajian yang mendalam terhadap substansi peraturan yang lebih tinggi sangat membantu DPRD dan gubernur/bupati/walikota dalam menetapkan peraturan daerah dengan kualitas yang baik dan sekaligus menghindari kemungkinan "pembatalan Perda" oleh Pemerintah dan merepotkan DPRD dan Kepala Daerah untuk menetapkan Perda tentang pencabutan Perda.

Bagaimana kedudukan Peraturan Daerah dalam hierarki perundang-undangan? Dari segi pembuatannya, sudah semestinya kedudukan Perda ini, baik Perda Propinsi maupun Perda Kabupaten atau Kota, dapat dilihat setara dengan Undang-Undang dalam arti semata-mata merupakan produk hukum lembaga legislatif. Namun demikian, dari segi isinya sudah seharusnya, kedudukan peraturan yang mengatur materi dalam ruang lingkup. daerah berlaku yang lebih sempit dianggap mempunyai kedudukan lebih rendah dibandingkan peraturan dengan ruang lingkup wilayah berlaku yang lebih luas. Dengan demikian, Undang-Undang lebih tinggi kedudukannya daripada Perda Propinsi, dan Perda Kabupaten atau Perda Kota. Karena itu, sesuai prinsip hierarki peraturan perundangundangan, peraturan yang lebih rendah itu tidak boleh bertentangan dengan peraturan yang derajatnya lebih tinggi. ${ }^{14}$

Akan tetapi, sebagai konsekuensi dipertegasnya prinsip pemisahan kekuasaan eksekutif, legislatif dan judikatif dalam naskah Perubahan Pertama UUD 1945 maka produk legislatif daerah ini dapat saja bertentangan dengan produk eksekutif di tingkat pusat. Misalnya, apabila suatu materi Perda propinsi ataupun Perda kabupaten/kota yang telah ditetapkan secara sah ternyata bertentangan isinya dengan materi Peraturan Menteri di tingkat pusat, maka pengadilan haruslah menentukan bahwa Perda itulah yang berlaku sepanjang untuk daerahnya. ${ }^{15}$

Menurut Bagir Manan, mengingat bahwa Perda (termasuk Peraturan Desa) dibuat oleh satuan pemerintahan yang mandiri (otonom), dengan lingkungan wewenang yang mandiri pula, maka dalam pengujiannya terhadap peraturan perundang-undangan yang lebih tinggi tidak boleh semata-mata berdasarkan "pertingkatan", melainkan juga pada "lingkungan wewenangnya". Suatu Perda yang bertentangan dengan suatu peraturan perundang-undangan tingkat lebih tinggi (kecuali UUD) belum tentu salah, kalau ternyata peraturan perundang-undangan tingkat tinggi yang melanggar hak dan kewajiban daerah yang dijamin UUD atau UU Pemerintahan Daerah. ${ }^{16}$

Dalam rangka pengawasan terhadap Raperda dan Peraturan Kepala Daerah tentang APBD, perubahan APBD dan pertanggungjawaban pelaksanaan APBD, Penjelasan Umum angka 9 UU No. 32 Tahun 2004 menegaskan, dalam hal pengawasan terhadap rancangan Perda dan Perda, Pemerintah melakukan dengan 2 (dua) cara sebagai berikut:

1. Pengawasan terhadap rancangan

\footnotetext{
${ }^{14}$ Ni'matul Huda, Otonomi Daerah, (Pustaka Pelajar, Yogyakarta, 2005), hlm. 239.

${ }^{15}$ Bagir Manan, Teori..., Op.Cit., hlm. 279-280.

${ }^{16} \mathrm{Ibid}$., hlm. 142.
} 
peraturan daerah (RAPERDA), yaitu terhadap rancangan peraturan daerah yang mengatur pajak daerah, retribusi daerah, APBD, dan RUTR sebelum disahkan oleh kepala daerah terlebih dahulu dievaluasi oleh Menteri Dalam Negeri untuk Raperda provinsi, dan oleh Gubernur terhadap Raperda kabupaten/ kota. Mekanisme ini dilakukan agar pengaturan tentang hal-hal tersebut dapat mencapai daya guna yang optimal.

2. Pengawasan terhadap semua peraturan daerah di luar yang termasuk dalam angka 1 , yaitu setiap peraturan daerah wajib disampaikan kepada Menteri Dalam Negeri untuk provinsi dan Gubemur untuk kabupaten/kota untuk memperoleh klarifikasi. Terhadap peraturan daerah yang bertentangan dengan kepentingan umum dan peraturan yang lebih tinggi dapat dibatalkan sesuai mekanisme yang berlaku.

Pengaturan di atas merupakan koreksi terhadap sistem pengawasan represif yang dijalankan oleh UU No. 22 Tahun 1999. Di samping itu, karena banyak Perda yang selama ini bertentangan dengan kepentingan umum atau peraturan yang lebih tinggi. Langkah yàng ditempuh Pemerintah sebelum melaksanakan pengawasan represif memang sebaiknya juga melakukan pembinaan (evaluasi) kepada daerah, khususnya dalam pembuatan Perda secara berkelanjutan, Raperda yang kurang tepat segera dikembalikan untuk direvisi. Sehingga kemungkinan adanya kesalahan dalam pembuatan Perda dapat diminimalisir sejauh mungkin.
Mengingat tugas pemerintah daerah dalam rangka otonomi daerah semakin berat, maka pembentukan Perda, peraturan kepala daerah dan keputusan kepala daerah memerlukan perhatian yang serius. Proses harmonisasi, pembulatan dan pemantapan konsep rancangan Perda merupakan hal yang harus ditempuh. Pengharmonisan adalah merupakan upaya untuk menyelaraskan sesuatu, dalam hal ini Perda sebagai salah satu jenis peraturan perundang-undangan yang tersusun secara sistematis dalam suatu hierarki maupun dengan asas peraturan perundang-undangan agar tergambar dengan jelas dalam pemikiran atau pengertian bahwa Perda merupakan bagian integral yang utuh dari keseluruhan sistem peraturan perundangundangan. Pengharmonisan dilakukan untuk menjaga keselarasan, kebulatan konsepsi peraturan perundang-undangan sebagai sistem agar peraturan perundang-undangan berfungsi secara efektif. ${ }^{17} \mathrm{Di}$ samping itu, penghamonisan peraturan perundang-undangan sangat strategis fungsinya sebagai upaya preventif untuk mencegah adanya pembatalan oleh pemerintah atau pun diajukannya permohonan pengujian peraturan perundang-undangan kepada Kekuasaan Kehakiman yang kompeten. Pengharmonisasian akan menjamin proses pembentukan rancangan peraturan daerah dilakukan secara taat asas demi kepastian hukum. Adapun aspek-aspek apa yang perlu diharmonisasikan, setidaknya ada dua aspek yaitu yang berkaitan dengan konsepsi materi muatan dan teknik penyusunannya.

${ }^{17}$ A.A. Oka Mahendra, Harmonisasi dan Sinkronisasi RUU dalam Rangka Pemantapan dan Pembulatan Konsepsi, makalah "Workshop Pemahaman UUNo. 10 Tahun 2004 tentang Pembentukan Peraturan PerundangUndangan", Yogyakarta, Oktober 2005. 


\section{Simpulan}

Dari uraian di atas dapat disimpulkan bahwa dari segi pembuatannya, sudah semestinya kedudukan Perda ini, baik Perda Propinsi maupun Perda Kabupaten atau Kota, dapat dilihat setara dengan Undang-Undang dalam arti semata-mata merupakan produk hukum lembaga legislatif. Namun demikian, dari segi isinya sudah seharusnya, kedudukan peraturan yang mengatur materi dalam ruang lingkup daerah berlaku yang lebih sempit dianggap mempunyai kedudukan lebih rendah dibandingkan peraturan dengan ruang lingkup wilayah berlaku yang lebih luas. Dengan demikian, Undang-Undang lebih tinggi kedudukannya daripada Perda Propinsi, dan Perda Kabupaten atau Perda Kota.

Dalam pengujlannya terhadap peraturan perundang-undangan yang lebih tinggi tidak boleh semata-mata berdasarkan "pertingkatan", melainkan juga pada "lingkungan wewenangnya". Suatu Perda yang bertentangan dengan suatu peraturan perundang-undangan tingkat lebih tinggi (kecuali UUD) belum tentu salah, kalau ternyata peraturan perundangundangan tingkat tinggi yang melanggar hak dan kewajiban daerah yang dijamin UUD atau UU Pemerintahan Daerah.

\section{Daftar Pustaka}

A.A. Oka Mahendra, Harmonisasi dan Sinkronisasi RUU dalam Rangka Pemantapan dan Pembulatan Konsepsi, makalah "Workshop
Pemahaman UU No. 10.Tahun 2004 tentang Pembentukan Peraturan Perundang-Undangan", Yogyakarta, Oktober 2005.

A. Hamid S. Attamimi, Peranan Keputusan Presiden RI dalam Penyelenggaraan

Pemerintahan Negara (Suatu Studi Analisis Mengenai Keputusan Presiden yang Berfungsi Pengaturan dalam Kurun Waktu Pelita I - Pelita VI), Disertasi Doktor, Pascasarjana Universitas Indonesia, Jakarta, 1990.

Bagir Manan, Teoridan Polftik Konstitusi, Cetakan

Kedua, FH Uil Press, Yogyakarta, 2004

Hans Kelsen, General Theory of Law and State,

$\therefore$ - Translate by Anders Wedberg, Russell \& Russell, New York, 1973.

K.C. Wheare, Modem Constitution, Oxford University Press, London, 1971.

Ni'matul Huda, Negara Hukum, Demokrasi dan Judicial Review, UII Press, Yogyakarta, 2005.

Otonomi Daerah, Pustaka Pelajar, Yogyakarta, 2005.

Padmo Wahjono (Penghimpun), Masalah Ketatanegaraan Dewasa Ini, Ghalia Indonesia, 1984.

Rosjidi Ranggawidjaja, Pedoman Teknik Perancangan Peraturan Perundangundangan, Cita Bhakti Akademika, Bandung, 1996.

UU No. 10 Tahun 2004 tentang Pembentukan Peraturan Perundang-Undangan.

UU No. 32 Tahun 2004 tentang Pemerintahan Daerah 